\title{
The Impact of Employee Characteristics \\ in the Relation of Financial Knowledge, Financial Management Behavior and Personal Income with Investment Decision of Employee
}

\author{
Stella Natasha Asmara \\ Soegijapranata Catholic University \\ oei.stella@gmail.com \\ Andreas Lako \\ Soegijapranata Catholic University \\ oei.stella@gmail.com \\ Eny Trimeiningrum \\ Soegijapranata Catholic University \\ oei.stella@gmail.com
}

\begin{abstract}
The resarch is to analyze the impact of financial knowledge, financial management behavior, and personal income on investment decision of the employees of PT. Industri Jamu dan Farmasi Sido Muncul Tbk. This study is also to analyze moderating effect of employee' characteristics in relation to financial knowledge and financial management behavior and personal income to investment decision of the employees. Based on purposive sampling and questionnaire, the study results in financial knowledge, financial management behavior, and personal income have positive impact on investment decision of the employees. However, employee' characteristics do not show moderating effect in relations to financial knowledge and management behavior and personal income to investment decision of the employees. The results inidicate that emloyees' characteristics (risk taker or risk adverse) weaken the influence of financial knowledge, financial management behavior, and personal income to investment decision of the employees.
\end{abstract}

Keywords: financial knowledge, financial behavior, level of income, employees' characteristic, investment decision

\section{INTRODUCTION}

Individual realizes importance of investment as the response to conditions in the future that are considerably getting harder. There are many types of investment in Indonesia such as saving, properties, shares, etc. An individual may consider many factors in selecting types of investment. As seen in the case of the employees of PT. Industri Jamu \& Farmasi Sido Muncul Tbk, there are many types of investment selected by the employees who have variety 
background in financial knowledge, financial management behavior, personal income, and characteristics. Such phenomenon is interesting and important for being researched since each individual has unique point of view and opinion in making investment.

Financial knowledge is important since it is a basic critical factor in making financial decisions (Ida \& Dwinta, 2010). Furthermore, financial management behavior also takes role in an individual financial responsibility which relates to how they manage their finance (Ida \& Dwinta, 2010). The research of Xiao et al., (2006, in Aminatuzzahra. 2014) shows that an individual who has taken credit counseling can follow hirarchical pattern in financial management behavior like paying debts and adjusting expenses before taking out the saving. It is also apparent that evel of income influences investment decision of an individual; the amount of income determines how much allocated for investment. It can be stated that there is high probability that an individual having available resources (income) will show financial management behavior that is more responsible to money because available money (income) gives them chances to behave responsibly (Ida \& Dwinta, 2010).

There are two purposes of this research. The first is to analyze the impact of financial knowledge, financial management behavior, and personal income on investment decision of an employee. The second purpose is to analyze the impact of employee's characteristics as the moderating variable in relation to the impact of financial knowledge, financial management behavior, and personal income on investment decision of an employee.

This research will benefit investors in terms of motivating them to increase financial knowledge, giving them considerations in financial management behavior to make investemetn decisions, and increasing investment since they know other investment instruments. In relation to knowledge development, the the results of the research can be the reference for other research by addding variables that are relevant. 


\section{LITERATURE REVIEW}

\section{Investment}

Investment is basically to allocate a particular amount of money at this time with the hope it can generate benefits in the future. In general, investment is divided into two: investment on financial asset and investment on real asset. Investment on financial asset is conducted in money market in the form of for example certificate of deposit, commercial paper, other marketable securities. Investment can also be conducted in capital market in the form of for example share, obligation, warranty, option, etc. Meanwhile investment on real asset can be in the form of purchasing of productive assets, building a factory, opening mining, plantation, etc. (Halim, 2005).

According to Pratiwi (2015), there are reasons for an individual does an investment: (a) to increase investor's welfare. The welfare is in terms of monetary welfare that is measured by adding current incomes and future income; (b) to reduce inflation level. By investing, an individual can save their wealth or belongings from lossing value due to inflation; (c) to have tax saving. Many countries produce regulations to encourage public investment through taxation facility given to people who wants to invest in particular areas.

\section{Financial Kbowledge}

Before going into investment world, an individual needs knowledge on investment. Such knowledge is important as the guidance for conducting investments that is highly risky and full of uncertainty (Halim, 2005). Many people want to make smart decisions about how to manage their expenses and investments and finally reach a paticular level of wealth. Practical approach to achieve the goals involves learning about specific financial activity encountered by an individual like recording and budgeting, banking and credit usage, saving and lending, tax payment, making main expenses (such as house and car), buying insurance, 
investing, and pension planning. It needs knowledge for managing personal finance systematically and successfully (Ida \& Dwinta, 2010).

To have financial knowledge needs to develop financial skill and learns to use financial tools. Financial skill is a technique to make decision in personal financial management. Budgeting, selecting investment, selecting insurance plan, and using credit are examples of financial skill. Financial tools are form and chart used in making decision on personal financial management (like cheque, credit card, debit card) (Garman, 1985 in (Ida \& Dwinta, 2010).

\section{Financial Management Behavior}

Financial management behavior relates to personal financial responsibility on how to manage their finance. Financial responsibility is process in managing money and other assets in a productive way. Menawhile, money management is process in acquiring and using financial assets. There are several elements in managing money effectively such as budget management, evaluation on the neccessaty to buy and borrow pension in reasonable time frame. The main task of money management is budgeting process. Budget is aimed to ensure that an individual is able to manage financial liabilities timely using incomes received in the same priode (Ida \& Dwinta, 2010).

\section{Personal Income}

Personal income is total gross revenue of an individual in a year that comprise of wages, businesses, and investments. Investopedia explains that personal income is personal revenue known as profit before tax and is used in calculating gross profit that is adjusted for income tax purpose. Personal income is calculated based on revenues from all sources. The major component of total income is wage and salary. Moreover, there are many other categories of income including revenue from rent, payment of government subsidy, interest 
revenue, and devidend revenue. Personal income is a good indicator for consumer demand in the future even though it is not perfect one (Hilgert et al., 2003 in (Andrew \& Linawati, 2014).

\section{Employee's Characteristics}

Kusumawati (2013) stated that there is relationship between demographic factors and deliberation in investment decision since the results showed that age, education, and income correlated to deliberation in investment decision. According to Fahmi (2012), the characteristics are: (1) be afraid of risk or risk avoider or risk averter. This characteristic leads the decision maker to be very carefully toward the decision he makes and very likely to take actions to avoid risks resulting from the decision. Business people with this characteristic is likey to be safety player. (2) like risk or risk seeker or risk lover. This characteristic refers to people who like risk. For these people, higher risk means higher profit they can get. Such principle is dominant and influences strongly every decision they make. Mental of risk seeker that is also called as risk lover is a mental usually belong to big business people. This character is generally also owned by rebels who usually want to work hard with the belief that they can get victory afterwards.

The research framework is as follows

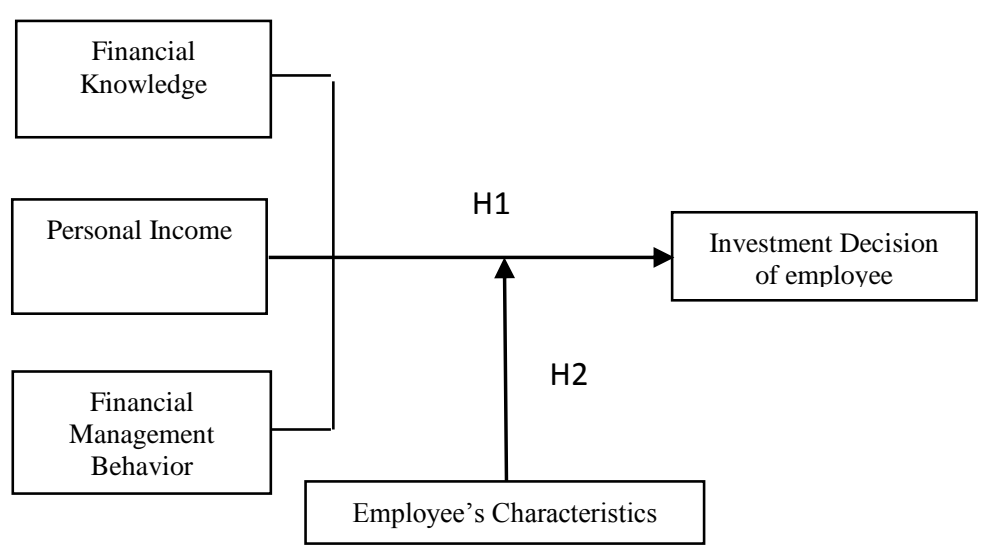

Figure 1. Research Framework 


\section{METHODS}

The object of this research is employees of PT. Industri Jamu dan Farmasi Sido Muncul Tbk. Samples were selected using purposive sampling based on the criteria: a permanent employee who has worked for more than 5 years, not a production staff, placed in Semarang, and ever did investment (saving, shares, deposit, asset, or others). The data were gathered using questionnaire.

\section{Operational Definition and Measurement of the Variables}

\section{Financial knowledge}

Financial knowledge is defined as knowledge to manage finance in making financial decision (Chen \& Volpe, 1998). The variable is measured using general knowledge on personal finance, saving and debt, insurance, and investment.

\section{Financial management behavior}

Financial management behavior is way in which individual manages fund sources (money) in deciding on the usage of fund, determiners of fund sources, and decision for pension plan (Zahroh, 2014). The indicators to measure the variable are organizing behavior, spending behavior, saving behavior, and disbursing behavior.

\section{Personal income}

Personal income is total gross income of an individual that can come from wages, salaries, businesses, and return on investment (Purwidianti \& Mudjiyanti, 2016). Personal income is measured using monthly gross income of an employee.

\section{Employee's characteristics}

Employee's characteristics is defined as action taken by an individual for highest utility that can be expected from it (Puspitaningtyas, 2012). The indicator used for this variable is level of risk taken by the individual. 


\section{Analysis Method}

The resarch applies quantitative analysis which is aimed at predicting the impact of several independent variables simultaneously and partially on the dependent variable quantitatively using statistical tools available in SPSS (Statistical Package for Sosial Science) for Windows 17 for testing the hypothesis. To test the impact of the independent variables on investment decision of employee, the following regression model is developed:

$$
\mathrm{KIK}=\beta_{0}+\beta_{1} \mathrm{PK}+\beta_{2} \mathrm{RK}+\beta_{3} \mathrm{TP}+\mathrm{e}
$$

In which:

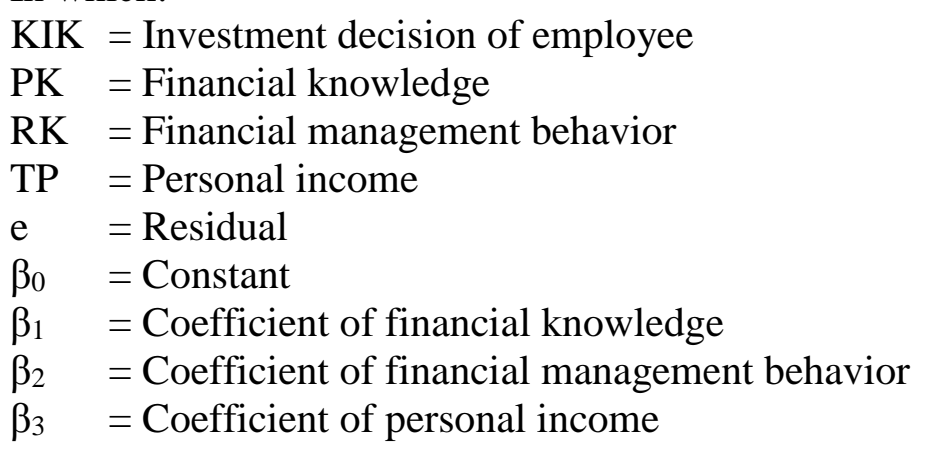

To test the impact of the independent variables and moderating variable on investment decision of employee, the following regression model is applied:

$\mathrm{KIK}=\beta_{0}+\beta_{1} \mathrm{PK}+\beta_{2} \mathrm{RK}+\beta_{3} \mathrm{TP}+\beta_{4} \mathrm{KI}+\beta_{5} . \mathrm{PK} * \mathrm{KI}+\beta_{6} . \mathrm{RK} * \mathrm{KI}+\beta_{7} . \mathrm{TP} * \mathrm{KI}+\mathrm{e} . .(2)$

In which:

KIK = Investment decision of employee

PK = Financial knowledge

RK = Financial management behavior

$\mathrm{TP} \quad=$ Personal income

KI $=$ Employee's characterisitcs

PK.KI = Interaction between financial knowledge and employee's characterisitcs

RK.KI = Interaction between financial management behavior and employee's characterisitcs

TP.KI = Interaction between personal income and employee's characterisitcs

$\mathrm{e} \quad=$ Residual

$\beta_{0} \quad=$ Constant

$\beta_{1-7}=$ Coefficient of each independent variable 


\section{RESULTS AND DISCUSSION}

\section{Profile of Respondents}

Table 1. Respondent based on Gender

\begin{tabular}{|l|c|c|}
\hline & Frequency & $\%$ \\
\hline Male & 30 & 27.80 \\
\hline Female & 78 & 72.20 \\
\hline Total & 108 & 100.00 \\
\hline
\end{tabular}

Source : Primary data, processed (2018)

Table 2. Respondent based on Age

\begin{tabular}{|l|c|c|}
\hline & Frequency & $\%$ \\
\hline $21-30$ years old & 21 & 19.40 \\
\hline $31-40$ years old & 77 & 71.30 \\
\hline$>40$ years old & 10 & 9.30 \\
\hline Total & 108 & 100.00 \\
\hline
\end{tabular}

Source : Primary data, processed (2018)

Table 3. Respondent based on Marital Status

\begin{tabular}{|l|c|c|}
\hline & Frequency & $\%$ \\
\hline Not married & 33 & 30.60 \\
\hline Married & 75 & 69.40 \\
\hline Total & 108 & 100.00 \\
\hline
\end{tabular}

Source : Primary data, processed (2018)

Table 4. Respondent based on Education

\begin{tabular}{|l|c|c|}
\hline & Frequency & $\%$ \\
\hline Senior High School & 20 & 18.50 \\
\hline Diploma (D3) & 18 & 16.60 \\
\hline Bachelor & 67 & 62.00 \\
\hline Master & 3 & 2.80 \\
\hline Total & 108 & 100.00 \\
\hline
\end{tabular}

Source : Primary data, processed (2018)

\section{Descriptive Statistic}

Descriptive statistic gives description on data that are presented in mean, standard of deviation, maximum, minimum of each variable (Ghozali, 2016). The descriptive statistic resulted from this research is as presented in table 5. 
Table 5. Descriptive Statistic

\begin{tabular}{|l|c|r|r|r|r|}
\hline & $\mathrm{N}$ & Minimum & Maximum & Mean & $\begin{array}{c}\text { Std. } \\
\text { Deviation }\end{array}$ \\
\hline Financial Knowledge & 108 & 43.00 & 90.00 & 65.6019 & 8.35759 \\
\hline $\begin{array}{l}\text { Financial Management } \\
\text { Behavior }\end{array}$ & 108 & 46.00 & 80.00 & 59.4907 & 7.10600 \\
\hline Personal Income & 108 & 1.00 & 4.00 & 1.9722 & .42047 \\
\hline $\begin{array}{l}\text { InvestmentDecision of } \\
\text { Employee }\end{array}$ & 108 & 22.00 & 45.00 & 34.1204 & 4.63977 \\
\hline Employee's Characteristics & 108 & 7.00 & 20.00 & 14.0556 & 2.85419 \\
\hline
\end{tabular}

Source: Primary data, processed (2018)

The variable of financial knowledge comprises 18 questions with 5 scale response. Based on mean, it can be stated that response of the respondents' on average is considered as high, which means that knowledge to manage finance in making financial decision is good. The variable of financial management behavior contains 16 questions with 5 scale response. Refering to mean value, response of the respondents on this variable is also considerably high, which means that way of the employees in this company to manage fund sources (money) for the purpose of fund usage, determiners of fund sources, and pension decision and long-term decision has been good. The variable of personal income only covers one question with 5 choices of response comprising range of income received by the respondents in a month. The mean is 1.9722 which means that majority respondents have income between Rp2,500,000,- and Rp7,500,000,-. Having 9 questions with 5 scale response, the mean value of the variable of investment decision of employee suggests that the respondents have thought about investment alternatives for either emergency or long-term decisions. The mean value of the variable of employee's characteristics covering 4 questions with 5 scale response indicates that the respondents have courage to do investment from either income or debts. 


\section{Testing hypothesis 1}

The resuls of the test on the first hypothesis on the impact of financial knowledge, financial management behavior, and personal income on investment decision of employee presented in table 6 are based on the following multiple regression analysis

$$
\mathrm{KIK}=\beta_{0}+\beta_{1} \mathrm{PK}+\beta_{2} \mathrm{RK}+\beta_{3} \mathrm{TP}+\mathrm{e}
$$

Table 6. Model of the impact of financial knowledge, financial management behavior, and personal income on investment decision of employee

\begin{tabular}{|l|c|c|c|}
\hline Variable & \multicolumn{1}{|c|}{ B } & t & Sig. \\
\hline Financial knowledge (PK) & 0.170 & 1.675 & $0.097^{* *}$ \\
\hline $\begin{array}{l}\text { financial management } \\
\text { behavior (RK) }\end{array}$ & 0.200 & 1.969 & $0.052^{* *}$ \\
\hline Personal income (TP) & 0.227 & 2.524 & $0.013^{*}$ \\
\hline F & \multicolumn{3}{|c|}{6.935} \\
\hline Adjusted R 2 & \multicolumn{3}{|c|}{0.143} \\
\hline Sig. & \multicolumn{3}{|c|}{0.000} \\
\hline
\end{tabular}

Keterangan:

$* \operatorname{Sig} 5 \%$

$* * \operatorname{Sig} 10 \%$

Sumber: Data Primer yang Diolah (2018)

The value of $\mathrm{F}$ amounting 6.935 and sig. $0.000<0.05$ means that the hypothesis $\mathrm{H} 1$ stating that "financial knowledge, financial management behavior, and personal income have positive impact on investment decision of employee" is accepted. The Adjusted $\mathrm{R}^{2}$ is 0.143 which means that the independent variables influence the changes of the dependent variable as much as $14.3 \%$.

The results of this research support previous research conducted by Halim (2005) stating that investors need relevant information as the basis for making investment decision. Based on the information, they then create a decision making model comprising evaluation criteria enabling the investor to select the best investment among the available alternatives. 


\section{Testing hypothesis 2}

The results of the test on the second hypothesis on the effect of moderating variable of employee's characteristics in relation to the impact of financial knowledge, financial management behavior, and personal income on investment decision of employee presented in table 7 are based on the following model.

$\mathrm{KIK}=\beta_{0}+\beta_{1} \mathrm{PK}+\beta_{2} \mathrm{RK}+\beta_{3} \mathrm{TP}+\beta_{4} \mathrm{KI}+\beta_{5} \cdot \mathrm{PK} * \mathrm{KI}+\beta_{6} \cdot \mathrm{RK} * \mathrm{KI}+\beta_{7} \cdot \mathrm{TP} * \mathrm{KI}+\mathrm{e}$

Table 7. Model of Effect of Moderating Variable Employee's Characteristics in Relation to the Impact of Financial Knowledge, Financial Management Behavior, and Personal Income on Investment Decision of Employee

\begin{tabular}{|l|r|r|l|}
\hline Variable & B & \multicolumn{1}{|c|}{$\mathrm{t}$} & Sig. \\
\hline PK & -0.102 & -2.135 & $0.035^{* *}$ \\
\hline RK & -0.330 & -6.335 & $0.000^{*}$ \\
\hline TP & -0.257 & -5.667 & $0.000^{*}$ \\
\hline KI & -0.021 & -1.873 & $0.064^{* * *}$ \\
\hline PK.KI & 0.257 & 2.613 & $0.010^{*}$ \\
\hline RK.KI & 0.665 & 6.236 & $0.000^{*}$ \\
\hline TP.KI & 0.371 & 6.102 & $0.000^{*}$ \\
\hline Nilai F & \multicolumn{3}{|c|}{1620.202} \\
\hline Adjusted R R $^{2} 0.991$ \\
\hline Sig. & \multicolumn{3}{|c|}{0.000} \\
\hline
\end{tabular}

Notes:

$* \operatorname{Sig} 1 \%$

$* * \operatorname{Sig} 5 \%$

$* * *$ Sig $10 \%$

Source: Primary data, processed (2018)

From table 7, it can be stated that value of $\mathrm{F}$ is 1620.202 (sig. 0.000). This means that the model is fit and thus it can be used further. The value of Adjusted $\mathrm{R}^{2}$ is 0.991 meaning that the independent variables influence the variety of the dependent variable as much as 99.1\%. The value of coefficient beta is negative, which means that there is no impact of interaction between employee'scharacteristics and financial knowledge, financial management behavior, and personal income on investment decision of employee. It can be said that employee's characteristics that are measured using level of risk taking do not 
strengthen the impact of financial knowledge, financial management behavior, and personal income on investment decision of employee. This indicates that investor's risk averse or risk taker does not guarantee to have the best investment decision of employee.

The variable of employee's characteristics refers to employee courage in facing risk from investment. Citing Fahmi (2012), employee's charactristics are divided into two: afraid of risk or risk avoider or risk averter and like risk or risk seeker or risk lover. This means that the variable of employee's characteristics weakens significantly the impact of financial knowledge, financial management behavior, and personal income on investment decision of employee. This can happened because lack of instruments used in the varible which is only four questions.

Of the four questions, the data show that the respondents can tolerate risk on for example bank liquidation and decrease on interest, but they have high risk on uncertain investment such as share and mutual fund. Thus, the respondents have high risk averse, which means they are afraid of uncertainty arising from an event and the uncertainty can cause loss.

Referring to the profile of the respondents, majority respondents are female and thus they are more likely risk averse and not risk taker because female are considerably less aggresive than male who prefer challenges and risks. Gender is therefore an important factor in classifying risk tolerance of investors because more men than women who have personality called as "sensation seeker" (Roszkowski et al., 1993). There is also a belief in the human culture that it is common for men to take higher risk than women do (Slovic, 1966).

Based on marital status, majority of the respondents have been married and thus they expense quite a lot. This makes them do not want to take risk by investing. Investors consider 
marital status (such as married, ever married, divorce, separate, and widow) as effective factor in differentiating tolerance level of investors (Roszkowski et al., 1993).

Moreover, majority of the respondents are dominated by those with middle to lower income, and thus the personal income is likely low. They spend most part of the income for basic needs and do not consider to invest and do not have courage to take investment risk. Puri (2018) stated that many know that investment is only for those with abundance. Such opinion may not totally wrong considering that investment usually involves much amount of money. However, it does not mean that those from middle class who have limited income cannot invest. Akbar (2017) added that those who have low income or even income below the provincial minimum wage (Upah Minimum Provinsi, $U M P$ ) think that collecting money is already difficult and so does for investing.

\section{CONCLUSION AND RECOMMENDATIONS}

\section{Conclusions}

Based on the analysis, it can be concluded that (1) Financial knowledge, financial management behavior, and personal income influence investment decision of employee. Thus, the first hypothesis is accepted. This means that higher financial knowledge, financial management behavior, and education will increase investment decision of employee. (2) Employee's characteristics cannot be moderating effect between financial knowledge, financial management behavior, personal income on investment decision of employee because characteristic of risk taker or risk adverse weakens the impact of financial knowledge, financial management behavior, and personal income on investment decision of employee. Thus, the second hypothesis is rejected. 


\section{Research Limitations}

The limitation of the research relates to the lack of instrument on employee's characteristics as an investor in the questionnaire. The reason for this is number of question for the variable of employee's characteristics is less than those of other variables. Also, the returned questionnairs are dominated by the respondents with lower middle personal income. This affects respondents' characterisitcs in making investment decision.

\section{Recommendations}

The recommendations suggested from the research are: (1) It will be better to add instrument on the first questionnaire especially those relate to the variable of employee's characteristics so that the data gathered can give better description about respondent responses. (2) Next similar research may not need to use personal income as the variable or may focus on respondents with middle upper income. (3) Next research can possibly add intervening variable instead of moderating variable such as age, education, gender because differences in gender and age can strengthen the impact on investment decision of employee.

\section{REFERENCES}

Akbar, A. (2017). Penghasilan Di Bawah UMP Tapi Mau Investasi? Begini Caranya. https://www.moneysmart.id/penghasilan-ump-mau-investasi-begini-caranya/

Aminatuzzahra. (2014). Persepsi Pengaruh Pengetahuan Keuangan, Sikap Keuangan, Sosial Demografi Terhadap Perilaku Keuangan Dalam Pengambilan Keputusan Investasi Individu. Universitas Diponegoro Semarang.

Andrew, V., \& Linawati, N. (2014). Hubungan Faktor Demografi dan Pengetahuan Keuangan Dengan Perilaku Keuangan Karyawan Swasta di Surabaya. Finesta, 2 (2), 35-39. Diakses dari: http://download.portalgaruda.org/article.php?article=193690\&val=6508\&title=Hubu ngan\%20Faktor\%20Demografi\%20dan\%20Pengetahuan\%20Keuangan\%20Dengan $\% 20$ Perilaku\%20Keuangan\%20Karyawan\%20Swasta\%20di\%20Surabaya

Chen, H. \& R. P. Volpe. (1998). An Analysis of Personal Financial Literacy Among College Students. http://citeseerx.ist.psu.edu/viewdoc/download?doi=10.1.1.392.4650\&rep=rep1\&type $=$ pdf 
Fahmi, I. (2012). Analisis Kinerja Keuangan. Bandung: Alfabeta.

Ghozali, I. (2016). Aplikasi Analisis Multivariate dengan Program IBM SPSS 23. Semarang: Badan Penerbit Universitas Diponegoro.

Halim, A. (2005). Analisis Investasi. Jakarta: Salemba Empat.

Ida, \& Dwinta, C. Y. (2010). Pengaruh Locus of Control, Financial Knowledge, Income Terhadap Financial Management Behavior. Jurnal Bisnis Dan Akuntansi, 12(3), 131-144. Diakses dari: http://jurnaltsm.id/index.php/JBA/article/view/202/178

Kusumawati, M. (2013). Faktor Demografi, Economic Factors dan Behavioral Motivation Dalam Pertimbangan Keputusan Investasi Di Surabaya. Jurnal Finesta, 1 (2), 30-35. Diakses dari: http://download.portalgaruda.org/article.php?article $=193554 \&$ val=6508\&title=Fakto r\%20Demografi,\%20Economic\%20Factors\%20dan\%20Behavioral\%20Motivation\% 20Dalam\%20Pertimbangan\%20Keputusan\%20Investasi\%20Di\%20Surabaya

Pratiwi, I., \& Prijati. (2015). Pengaruh Faktor Demografi Terhadap Jenis Investasi dan Perilaku Investor Pasar Modal Surabaya. Jurnal Ilmu Dan Riset Manajemen Volume, 4, 1-15. Diakses dari: https://anzdoc.com/pengaruh-faktor-demografi-terhadap-jenisinvestasi-dan-peril.html

Puri, D. (2018). 4 Jenis Investasi Ini Paling Populer Di Indonesia, Kamu Punya Salah Satunya?. https://www.moneysmart.id/ini-4-jenis-investasi-yang-simpel-danpopuler-di-indonesia/

Purwidianti, W. \& R. Mudjiyanti. (2016). Analisis Pengaruh Pengalaman Keuangan dan Tingkat Pendapatan Terhadap Perilaku Keuangan Keluarga di Kecamatan Purwokerto Timur. Diakses dari: https://www.researchgate.net/publication/313838982_Analisis_Pengaruh_Pengalam an_Keuangan_dan_Tingkat_Pendapatan_Terhadap_Perilaku_Keuangan_Keluarga_d i_Kecamatan_Purwokerto_Timur

Puspitaningtyas, Z. (2012). Perilaku Investor Dalam Pengambilan Keputusan Investasi di Pasar Modal, $19 . \quad$ Diakses dari: http://repository.unej.ac.id/bitstream/handle/123456789/58351/PERILAKU\%20INV ESTOR-sdh_1.pdf;sequence=1

Roszkowski, M. J.; Snelbecker,G. E.; Leimberg, S. R. (1993). Risk-tolerance and Risk Aversion", In S.R. Leimberg.

Slovic, P. (1966). Risk Taking in Children: Age and Sex Differences. Child Development, 37, 169-176. http://dx.doi.org/10.2307/1126437

Zahroh, F. (2014). Menguji Tingkat Pengetahuan Keuangan, Sikap Keuangan Pribadi, dan Perilaku Keuangan Pribadi Mahasiswa Jurusan Manajemen Fakultas Ekonomika dan Bisnis Semester 3 dan Semester 7. Diakses dari: http://eprints.undip.ac.id/45371/1/04_ZAHROH.pdf 